\title{
Efficacy of Trichocompost on the Growth and Yield of Tomato
}

\author{
Muhammad Saiful Abedin, Md. Ashraful Hoque ${ }^{*}$, Md. Atiqur Rahman Khokon, Ismail Hossain
}

Department of Plant Pathology, Bangladesh Agricultural University, Mymensingh-2202, Bangladesh

Copyright $\subseteq 2018$ by authors, all rights reserved. Authors agree that this article remains permanently open access under the terms of the Creative Commons Attribution License 4.0 International License

\begin{abstract}
A field experiment was conducted to investigate the efficacy of Trichocompost utilizing Trichoderma as biological agent. Three doses of Trichocompost viz. $500 \mathrm{~g} / \mathrm{m}^{2}, 750 \mathrm{~g} / \mathrm{m}^{2}, 1000 \mathrm{~g} / \mathrm{m}^{2}$ were applied including untreated control treatment. All the yield parameters were significantly higher when they were applied in different doses of Trichocompost. However, growth parameters did not show significant variation although luxuriant and lavish growth was noticed. Best performances were recorded by applying Trichocompost application @1000g/ $\mathrm{m}^{2}$. Economic analysis of the treatments indicates that Trichocompost is profitable for farmers. Benefit Cost Ratio (BCR) was maximum (2.26) in Trichocompost treated plot @1000g/ $/ \mathrm{m}^{2}$. It can be revealed that Trichocompost can be applied in the field for better tomato production.
\end{abstract}

Keywords Trichocompost, Trichoderma, Yield of
Tomato

\section{Introduction}

Tomato (Lycopersicum esculentum Mill) a member of the family Solanaceae, is the most popular vegetable in the world. The world crop area of tomato has increased by $164 \%$ in 40 years and the world consumption of tomatoes has increased by $314 \%$. In recent years, tomato consumption quantity increased at the average rate of $3 \%$ annually. (Nicola et. al. 2009 [1]). The worldwide production of tomatoes totaled 170.8 million tons. China, the leading producer of tomatoes, accounted for $31 \%$ of the total production. India and the United States followed with the second and third highest production of tomatoes in the world. In the European Union, tomatoes accounted for $23 \%$ of the total output of fresh vegetables in 2014 (Nag, 2017 [2]). In Bangladesh total area under tomato cultivation 67535 acres and the production was 368121 MT at 2015-2016 (Bangladesh Bureau of Statistics, 2017 [3]). It is the third most important vegetable crop in Bangladesh.
Tomatoes are known to be a rich source of vitamins, minerals and carotenoids, especially vitamin C, phosphorus, potassium, and lycopene. Tomato powder contain vitamin C $125 \mathrm{mg}$, lycopene $1.41 \mathrm{mg}$, iron $3.99 \mathrm{mg}$, phosphorus 173mg, calcium 80mg, magnesium $126 \mathrm{mg}$, Zinc $2.71 \mathrm{mg}$, copper $0.876 \mathrm{mg}$, manganese $1.83 \mathrm{mg}$, sodium $121.60 \mathrm{mg}$ and potassium $2805.8 \mathrm{mg}$ per $100 \mathrm{~g}$ (Srivastava et. al. 2013 [4]). Tomato contains total carotenoids: $67.43 \mathrm{mg}$ $\mathrm{kg}^{-1}$ and hydroxycinnamates: $90.87 \mathrm{mg} \mathrm{kg}^{-1}$ (Daniela, 2013 [5]).

Diseases are a major limiting factor for tomato production. Diseases can be classified into two groups. The first are those caused by infectious microorganisms that include fungi, bacteria, viruses and nematodes. These diseases are contagious and can spread from plant to plant in a field, often very rapidly when environmental conditions are favorable. The second group includes those caused by non-infectious physical or chemical factors, such as adverse environmental factors, nutritional or physiological disorders and herbicide injury. Non-infectious diseases cannot spread from plant to plant (Damicone et. al. 2016 [6]). In some instances, annual economic yield losses due to early blight have been estimated at 79\% (Adhikari et. al. 2017 [7]).Farmers generally use chemicals for controlling of these diseases. The indiscriminate use of chemicals for controlling disease of crop plants resulted environmental pollution, health hazards etc. As an alternate means of avoiding these problems, use of biological agents are being used for combating the diseases with the aim of increasing crop production. Biological control of plant pests and pathogens continues to inspire research and development in many fields. Plant pathogens are just one class of targets of biological control, which also is designed to limit other pests such as insects, parasitic nematodes, and weeds (Gardener et. al. 2002 [8]). Root colonization by Trichoderma spp. also frequently enhances root growth and development, crop productivity, resistance to abiotic stresses and the uptake and use of nutrients (Harman et. al. 2004 [9]). Several Trichoderma spp. positively affect plants by stimulating plant growth, and protecting plants 
from fungal and bacterial pathogens. They are used in biological plant protection as biofungicides as well as in bioremediation (Blaszczyk et. al. 2014 [10]). Trichoderma spp. can reduce the severity of plant diseases by inhibiting plant pathogens in the soil through their highly potent antagonistic and mycoparasitic activity (Hermosa, 2012 [11]).

Until recently, no endeavor has been reported to estimate the yield and cost benefit ration using a biofungicide on tomato in Bangladesh. Therefore, the present study was undertaken to achieve the following objectives:

i. To study the efficacy of Trichocompost on growth and yield of Tomato.

ii. To evaluate benefit cost ratio of Trichocompost for profitable production of Tomato.

\section{Materials and Methods}

The experiment was conducted at the Field laboratory, Department of Plant Pathology, Bangladesh Agricultural University, Mymensingh, Bangladesh. The experiment was laid out in the Randomized Complete Block Design (RCBD) with four replications. Distance between the blocks was $1 \mathrm{~m}$ and between the plots was $0.5 \mathrm{~m}$. The size of unit plot was $5 \mathrm{~m} \mathrm{X} 1 \mathrm{~m}$.

\section{Treatments of the experiments}

A total of 4 treatments were used designated as $T_{1}, T_{2}, T_{3}$, and $\mathrm{T}_{4}$ which were as follows:

$\mathrm{T}_{1}=$ Trichocompost @ $500 \mathrm{~g} / \mathrm{m}^{2}$

$\mathrm{T}_{2}=$ Trichocompost @750g/ $\mathrm{m}^{2}$

$\mathrm{T}_{3}=$ Trichocompost @1000g $/ \mathrm{m}^{2}$

$\mathrm{T}_{4}=$ Control

Fertilizer doses were: Cow dung-10 tons/ha, Urea-140 $\mathrm{kg} / \mathrm{ha}$, Triple Super Phosphate (TSP)-120 kg/ha, Muriate of Potash (MoP)-100 kg/ha. All TSP and half dose of MoP were applied during land preparation. Urea and remaining half dose of MoP were applied in installments as side dressing. Data on Plant height, Number of leaves per plant, Number of primary branches per plant, Number of secondary branches per plant, Number of fruits per plant, Fruit weight were recorded.

Four (4) soil samples were collected randomly from tomato field of Department of Plant Pathology Field laboratory, Bangladesh Agricultural University, Mymensingh.

\section{Preparation of Culture Media}

Potato dextrose agar (PDA) medium is formulated by Potato (peeled and sliced)- 200g, Dextrose-20g, Agar-17g \& Water-1000ml (Aryal, 2015 [12]). The prepared PDA was poured in $500 \mathrm{ml}$ screw-cap glass bottles and sterilized $\left(121^{\circ} \mathrm{C}, 15 \mathrm{psi}\right.$ for $\left.15 \mathrm{~min}\right)$. The media was acidified with 30 drops of $50 \%$ lactic acid per $250 \mathrm{ml}$ medium.

\section{Isolation of Soil Fungi}

Dilution plate technique (Warcup, 1955 [13]) for isolation of Trichoderma was followed:

\section{i. Preparation of working area}

The surface of the working area, hand and the glass wares were disinfected with cotton soaked in methylated spirit (70\%).

\section{ii. Making suspension (soil dilution)}

a) $1 \mathrm{gm}$ of the soil was placed in test tube containing $9 \mathrm{ml}$ of sterile water and stirred thoroughly for few minutes in order to obtain a uniform 1:10 dilute soil suspension. This was used as stock suspension.

b) $1 \mathrm{ml}$ of that 1:10 stock suspension was transferred with the help of sterile pipette into the $2^{\text {nd }}$ test tube containing $9 \mathrm{ml}$ sterile water and shaken thoroughly thus resulting $10^{-1}$ dilution.

c) $1 \mathrm{ml}$ of the dilution is transferred to $3^{\text {rd }}$ test tube containing $9 \mathrm{ml}$ sterile water by sterile pipette thus making $10^{-2}$ dilution. In this way dilution was made up to $10^{-4}$.

iii. Isolation of micro-organisms (fungi) from soil

a) $20 \mathrm{ml}$ of warm melted PDA medium was (approx. $45^{\circ} \mathrm{C}$ ) poured in each sterile Petri-plate.

b) $1 \mathrm{ml}$ of diluted soil sample $\left(10^{-2}\right.$ and $10^{-3}$ was placed at the center of PDA and spread. Four Petri-dishes each were inoculated with $1 \mathrm{ml}$ of diluted sample. This was repeated with every soil sample.

c) The inoculated PDA plates were incubated for 7-10 days at room temperature $\left(25 \pm 1^{\circ} \mathrm{C}\right)$.

d) The colonies grow out on PDA were recorded after 3-5 days. Sub cultures were made by transferring a small colony to a new Petri-dish on the basis of color and morphology of the colony. Further transfers were made for purification. The contaminated plates were discarded.

\section{Estimation of Soil Fungi}

The number of colonies developed in each PDA plates was counted and average values were calculated for each sample. Number of colonies per $\mathrm{ml}$ of soil suspension was calculated by its colony forming units (CFU). The number of $\mathrm{CFU} / \mathrm{g}$ sample was calculated by using following formula

Population of fungi $=$ Average number of total colonies $/ \mathrm{ml}$ in 4 Petri-dishes $\times$ Dilution factor $\left(10^{2}\right.$ and $\left.10^{3}\right)$.

\section{Benefit-Cost Ratio (BCR):}

The cost-benefit analysis was done to compare the profitability among the treatments. The BCR was calculated by slight modification of the formula as used by 
(Ramadas, 2014 [14]) is shown below:

Benefit cost ratio $(\mathrm{BCR})=$ Gross return $\div$ Total cost of
production

\section{Analysis of Data}

Data collected during experimental period were tabulated and analyzed through a standard computer package statistical procedure MSTAT-C. The mean values of individual treatments were compared by Least Significant Difference (LSD) test.

\section{Result}

\subsection{Effect of Different Treatments on Growth of Tomato Plant}

\subsubsection{Number of Leaves}

Number of leaves/plant varied among the treatments at different weeks. Initially the number of leaves/plant was influenced by supplementation with Trichocompost. The variation is more apparent at the earlier weeks. At $5^{\text {th }}$ week, the number of leaves/plant was almost similar (57, 56, 59, and 54 respectively at $T_{1}, T_{2}, T_{3}$ and $T_{4}$ Treatments) in all treatments including control plots where recommendation fertilizers were applied. (Table 1)

Table 1. Effect of Trichocompost on number of leaves of tomato plants

\begin{tabular}{|c|c|c|c|c|c|}
\hline \multirow{2}{*}{ Number of leaves } & \multicolumn{5}{|c|}{ Time interval (Week) } \\
\cline { 2 - 6 } & $1^{\text {st }}$ & $2^{\text {nd }}$ & $3^{\text {rd }}$ & $4^{\text {th }}$ & $5^{\text {th }}$ \\
\hline $\begin{array}{c}\mathrm{T}_{1} \text { (Trichocompost @500g } \\
/ \mathrm{m}^{2} \text { ) }\end{array}$ & 18 & 23 & 36 & 46 & 57 \\
\hline $\begin{array}{c}\mathrm{T}_{2} \text { (Trichocompost @750g } \\
/ \mathrm{m}^{2} \text { ) }\end{array}$ & 19 & 26 & 32 & 40 & 56 \\
\hline $\begin{array}{c}\mathrm{T}_{3} \text { (Trichocompost @1000g } \\
\left./ \mathrm{m}^{2}\right)\end{array}$ & 25 & 28 & 37 & 48 & $\mathbf{5 9}$ \\
\hline $\mathrm{T}_{4}$ (Control) & 17 & 22 & 28 & 43 & 54 \\
\hline
\end{tabular}

\subsubsection{Plant Height}

Supplementation of Trichocompost at different doses did not show significant variation in centimeter $(\mathrm{cm})$ unit until $2^{\text {nd }}$ week (Table 2).Interestingly application of Trichocompost at $500 \mathrm{~g} / \mathrm{m}^{2}$ showed highest plant height (49 $\mathrm{cm})$ at $5^{\text {th }}$ week.

Table 2. Effect of Trichocompost on plant height (cm) of tomato plants

\begin{tabular}{|c|c|c|c|c|c|}
\hline \multirow{2}{*}{ Treatments } & \multicolumn{5}{|c|}{ Time interval (Week) } \\
\cline { 2 - 6 } & $1^{\text {st }}$ & $2^{\text {nd }}$ & $3^{\text {rd }}$ & $4^{\text {th }}$ & $5^{\text {th }}$ \\
\hline $\begin{array}{c}\mathrm{T}_{1} \text { (Trichocompost @500g } \\
\left./ \mathrm{m}^{2}\right)\end{array}$ & 14 & 26 & 30 & 40 & $\mathbf{4 9}$ \\
\hline $\begin{array}{c}\mathrm{T}_{2} \text { (Trichocompost @750g } \\
\left./ \mathrm{m}^{2}\right)\end{array}$ & 14 & 23 & 26 & 35 & 42 \\
\hline $\begin{array}{c}\mathrm{T}_{3} \text { (Trichocompost @1000g } \\
\left./ \mathrm{m}^{2}\right)\end{array}$ & 14 & 28 & 32 & 36 & 41 \\
\hline $\mathrm{T}_{4}$ (Control) & 17 & 28 & 30 & 33 & 40 \\
\hline
\end{tabular}

\subsubsection{Number of Primary Branches}

Number of primary branches/plant was observed from $2^{\text {nd }}$ week to $4^{\text {th }}$ week. At beginning no. of primary branches were 4 , this higher number of branches were found at $750 \mathrm{~g} / \mathrm{m}^{2}$ Trichocompost application. The treatments were statistically difference at 3rd and 4th week. The highest number of branches (7) was observed in $T_{3}\left(1000 \mathrm{~g} / \mathrm{m}^{2}\right)$ which were followed by $\mathrm{T}_{2}$ and $\mathrm{T}_{1}$ treatments. Application of $1000 \mathrm{~g} / \mathrm{m}^{2}$ (Table 3).

Table 3. Effect of Trichocompost on primary branches of tomato plant

\begin{tabular}{|c|c|c|c|}
\hline \multirow{2}{*}{ Treatments } & \multicolumn{4}{|c|}{ Time interval (Week) } \\
\cline { 2 - 4 } & $2^{\text {nd }}$ & $3^{\text {rd }}$ & $4^{\text {th }}$ \\
\hline $\mathrm{T}_{1}$ (Trichocompost @500g $\left./ \mathrm{m}^{2}\right)$ & 2 & 4 & 5 \\
\hline $\mathrm{T}_{2}$ (Trichocompost @750g $\left./ \mathrm{m}^{2}\right)$ & 4 & 5 & 6 \\
\hline $\mathrm{T}_{3}$ (Trichocompost @1000g $\left./ \mathrm{m}^{2}\right)$ & 3 & 6 & 7 \\
\hline $\mathrm{T}_{4}$ (Control) & 2 & 3 & 4 \\
\hline
\end{tabular}

\subsubsection{Number of Secondary Branches}

Number of secondary branches varied in different treatments at different time intervals. The highest number of secondary branches 18 were recorded in $T_{3}\left(1000 \mathrm{~g} / \mathrm{m}^{2}\right)$ at $5^{\text {th }}$ week which is higher than control treatment $\left(\mathrm{T}_{4}\right)$. Treatment $T_{1}$ and $T_{2}$ also showed significantly higher number of secondary branches compared to control treatment $\left(\mathrm{T}_{4}\right)$. (Table 4$)$

Table 4. Effect of Trichocompost on secondary branches of tomato plants

\begin{tabular}{|c|c|c|c|}
\hline \multirow{2}{*}{ Treatments } & \multicolumn{3}{|c|}{ Time interval (Week) } \\
\cline { 2 - 4 } & $3^{\text {rd }}$ & $4^{\text {th }}$ & $5^{\text {th }}$ \\
\hline $\mathrm{T}_{1}$ (Trichocompost @500g $/ \mathrm{m}^{2}$ ) & 6 & 11 & 15 \\
\hline $\mathrm{T}_{2}$ (Trichocompost @750g $\left./ \mathrm{m}^{2}\right)$ & 7 & 11 & 16 \\
\hline $\mathrm{T}_{3}$ (Trichocompost @1000g $\left./ \mathrm{m}^{2}\right)$ & 7 & 15 & $\mathbf{1 8}$ \\
\hline $\mathrm{T}_{4}$ (Control) & 5 & 8 & 10 \\
\hline
\end{tabular}

\subsubsection{Number of Flowers}

Number of flowers per plant significantly varied in different treatments compares to control treatments. In both $6^{\text {th }}$ week (when the flowers stunted blooming) and $7^{\text {th }}$ week supplementation with Trichocompost increased number of flowers per plant. The highest no. of flowers was 36, observed in $\mathrm{T}_{3}$ which is higher than the control $\left(\mathrm{T}_{4}\right)$. (Table 5). It is evident from the experiment that supplementation with Trichocompost increased the number of flowers per plant compared to control.

Table 5. Effect of Trichocompost on number of flowers of tomato plant

\begin{tabular}{|c|c|c|}
\hline \multirow{2}{*}{ Treatments } & \multicolumn{2}{|c|}{ Time interval (Week) } \\
\cline { 2 - 3 } & $6^{\text {th }}$ & $7^{\text {th }}$ \\
\hline $\mathrm{T}_{1}$ (Trichocompost @500g $/ \mathrm{m}^{2}$ ) & 26 & 32 \\
\hline $\mathrm{T}_{2}$ (Trichocompost @750g $/ \mathrm{m}^{2}$ ) & 27 & 31 \\
\hline $\mathrm{T}_{3}$ (Trichocompost @1000g $/ \mathrm{m}^{2}$ ) & 30 & $\mathbf{3 6}$ \\
\hline $\mathrm{T}_{4}$ (Control) & 19 & 22 \\
\hline
\end{tabular}




\subsubsection{Number of Fruits}

Number of fruits per plant significantly varied in different treatments. Supplementation with Trichocompost increased number of fruits in both weeks. Application of Trichocompost @1000g/ $\mathrm{m}^{2}$ in $\mathrm{T}_{3}$ treatment was the highest number of fruits/plants (36) which was higher than control plot $\left(\mathrm{T}_{4}\right)$. (Table 6)

Table 6. Effect of Trichocompost on number of fruits in tomato plant

\begin{tabular}{|c|c|c|}
\hline \multirow{2}{*}{ Treatments } & \multicolumn{2}{|c|}{ Time interval (Week) } \\
\cline { 2 - 3 } & $7^{\text {th }}$ & $8^{\text {th }}$ \\
\hline $\mathrm{T}_{1}$ (Trichocompost @500g $\left./ \mathrm{m}^{2}\right)$ & 26 & 32 \\
\hline $\mathrm{T}_{2}$ (Trichocompost @750g $\left./ \mathrm{m}^{2}\right)$ & 27 & 31 \\
\hline $\mathrm{T}_{3}$ (Trichocompost @1000g $\left./ \mathrm{m}^{2}\right)$ & 30 & 36 \\
\hline $\mathrm{T}_{4}$ (Control) & 19 & 22 \\
\hline
\end{tabular}

\subsection{Effect of Different Treatments on Benefit-Cost Ratio (BCR) of Tomato Plant}

\subsubsection{Yield}

Yield of tomato per plot significantly varied in different treatment. The highest yield was recorded in $\mathrm{T}_{3}(5.75$ $\mathrm{kg} / \mathrm{plot}$ ) which were followed by $T_{1}$ and $T_{2}$. In control plot, where recommended fertilizer was applied gave $4 \mathrm{~kg}$ tomato per plot. Application of Trichocompost @ $1000 \mathrm{~g} / \mathrm{m}^{2}$ gave the highest yield (5.75 kg) which was $43.75 \%$ higher than the control plot $\mathrm{T}_{4}$. (Table 7)

Table 7. Effect of Trichocompost on yield of tomato plant

\begin{tabular}{|c|c|c|}
\hline Treatments & $\begin{array}{c}\text { Yield } \\
\text { (Kg/Plot) }\end{array}$ & $\begin{array}{c}\text { Total } \\
\text { yield } \\
\text { (t/ha) }\end{array}$ \\
\hline $\mathrm{T}_{1}$ (Trichocompost @500g $/ \mathrm{m}^{2}$ ) & 5.00 & 10 \\
\hline $\mathrm{T}_{2}$ (Trichocompost @750g $\left./ \mathrm{m}^{2}\right)$ & 5.00 & 10 \\
\hline $\mathrm{T}_{3}$ (Trichocompost @1000g $/ \mathrm{m}^{2}$ ) & $\mathbf{5 . 7 5}$ & $\mathbf{1 1 . 5}$ \\
\hline $\mathrm{T}_{4}$ (Control) & 4.00 & 8 \\
\hline
\end{tabular}

\subsubsection{Cost-benefit Analysis}

The result from the cost-benefit analysis reveal that the maximum gross return was obtained from Trichocompost $\left(\mathrm{T}_{3}\right)$ treatment (TK.230000). Benefit cost ratio (BCR) was also the highest (2.26) in Trichocompost $\left(\mathrm{T}_{3}\right)$ treatment (Table 8).

The second highest gross return was obtained from $\left(T_{1}\right)$ treatment and BCR was (2.20). Here treatment (T3) was better than control (T4) because Disease Incidence (\%DI) of late blight and leaf curl of T3 treatment were 3.59\% and $1.79 \%$ respectively less than $\mathrm{T} 4$ treatment $(7.16 \%, 7.28 \%$ respectively) (Table 9).

The least return was obtained from the control treatment $\mathrm{T}_{4}$ (TK. 160000. $\mathrm{BCR}=1.90$ ).

Table 8. Cost and return of tomato with treatment combination

\begin{tabular}{|c|c|c|c|c|c|}
\hline Treatments & $\begin{array}{c}\text { Total yield } \\
\text { (t/ha) }\end{array}$ & $\begin{array}{c}\text { Gross return } \\
\text { (TK/ha) }\end{array}$ & $\begin{array}{c}\text { Total cost of } \\
\text { production }\end{array}$ & $\begin{array}{c}\text { Net return/ loss } \\
\text { (TK/ha) }\end{array}$ & $\begin{array}{c}\text { Benefit cost } \\
\text { ratio(BCR) }\end{array}$ \\
\hline T1 & 10 & 200000 & 90646.48 & 109353.52 & 2.20 \\
\hline T2 & 10 & 200000 & 96096.48 & 103903.52 & 2.08 \\
\hline T3 & 11.5 & 230000 & 101546.48 & 128453.52 & 2.26 \\
\hline T4 & 8 & 160000 & 84106.48 & 75893.52 & 1.90 \\
\hline
\end{tabular}

$\mathrm{T}_{1}=$ Trichocompost @500g $/ \mathrm{m}^{2} \mathrm{~T}_{2}=$ Trichocompost @750g/ $\mathrm{m}^{2} \mathrm{~T}_{3}=$ Trichocompost @1000g $/ \mathrm{m}^{2} \mathrm{~T}_{4}=$ Control

Table 9. Disease incidence of late blight and leaf curl diseases of tomato

\begin{tabular}{|c|c|c|}
\hline Treatments & Incidence (\%) of late blight & Incidence (\%) of leaf curl \\
\hline $\mathrm{T}_{1}$ (Trichocompost @500g $\left./ \mathrm{m}^{2}\right)$ & 7.01 & 5.63 \\
\hline $\mathrm{T}_{2}$ (Trichocompost @750g $\left./ \mathrm{m}^{2}\right)$ & 7.28 & 4.05 \\
\hline $\mathrm{T}_{3}$ (Trichocompost @1000g $\left./ \mathrm{m}^{2}\right)$ & $\mathbf{3 . 5 9}$ & $\mathbf{1 . 7 9}$ \\
\hline $\mathrm{T}_{4}$ (Control) & 7.16 & 7.28 \\
\hline
\end{tabular}

Sale price of Tomato @ TK.20000/t, i.e. TK. 20.00/kg

Gross return $(T K / h a)=$ yield $(t / h a) \times$ price per ton

Benefit cost ratio $(\mathrm{BCR})=$ Gross return $\div$ Total cost of production (Table 8 ) 


\section{Discussion}

Significant effect of Trichocompost was recorded on growth parameters of tomato like plant height, number of leaves, number of primary branches, secondary branches, number of flowers, number of fruits, yield and yield contributing characters. Treatment $\mathrm{T}_{2}$ and $\mathrm{T}_{3}$ (Trichocompost prepared by using $750 \mathrm{~g} / \mathrm{m}^{2}$ and $1000 \mathrm{~g} / \mathrm{m}^{2}$ Trichoderma respectively) were superior in most cases. It was also found that there was a less differences among Trichoderma treated compost $\left(\mathrm{T}_{1}, \mathrm{~T}_{2}\right.$ and $\left.\mathrm{T}_{3}\right)$ but sharp difference was observed in case of $\mathrm{T}_{4}$ (without Trichocompost). The number of leaves was affected by different treatments in tomato. Highest number of leaves was obtained in $\mathrm{T}_{3}$. Shahiduzzaman (2009) [15] found $T$. harzianum present in decomposed municipality waste significantly effective in eliciting increased growth response by increasing number of leaves. Rahman (et. al. 2010) [16] found that inorganic fertilizers (NPK) with Tricho-compost is suitable for better production of chili that may increase soil fertility and this integrated approach could be contributed to improve crop production. This experiment showed higher no of flowers and fruits that enhanced yield of tomato over the control plot which is similar to the result of (Naznin et. al. 2015 [17]). They found In case of plant height, number of leaves per plant, plant spread, days to flowering, number of florets, flower yield, bulb production, Tricho-compost + RDF gave superior results over control (Recommended doses of fertilizer). The data obtained from the experiment showed that Tricho-compost with fertilizer enhanced qualitative and quantitative characters of tuberose flowers.

The present study reflects that the total number of branches per plant increased gradually with increasing Tricho-compost. This Tricho-compost produced more branches than any other treatments. Tricho-compost contains well decomposed materials and due to mixing of soil may help vigorous growth result more branches than field soil. Abd-El-Khair (et. al. 2010) [18] also found the average number of branches per plant as a result of application of Trichoderma spp. in the range of 5.0-6.3 branch/plant, compared to 3.7 branch/ plant in control treatment.

In this study yield of tomato per plot was significantly influenced by different treatments. Trichocompost showed better performance in producing maximum yield. Abd-El-Khair (et. al. 2010) [18] also found that the average fresh weight of pods in bean were in the range of 43.1-77.4g in case of Trichoderma treated, compared to $42.5 \mathrm{~g}$ in the control plants.

According to cost benefit analysis Trichocompost (@1000g/ $\mathrm{m}^{2}$ ) gave the highest return.

\section{Conclusions}

IPM Lab developed Tricho-compost is used as a good source of Trichoderma which should be applied immediate before planting and one or two times foliar spraying is effective for disease suppression. This will help the farmers to reduce the production cost, avoiding haphazard and excess application of toxic chemicals which often have their residual effects in the soil, in plants, in fruits and also in the farmers' body. From the experiment, it can be concluded that the plant height, number of leaves, primary branches, secondary branches, number of flower number of fruits, yield of fruits increasing significantly by Trichocompost application @1000g/m². Moreover, higher economic return can be obtained by Trichocompost application @1000g/ $\mathrm{m}^{2}$ which is also eco-friendly.

\section{REFERENCES}

[1] Nicola, S. and Tibaldi, G. \& Fontana, E. 2009. Crops, Agroselviter-Vegetable \& Plants, Aromatic. Tomato Production Systems and Their Application to the Tropics. Acta horticulturae. 821. 27-34p.

[2] Nag, O. S. 2017. The World's Leading Producers of Tomatoes.

https://www.worldatlas.com/articles/which-are-the-world-s -leading-tomato-producing-countries.html.

[3] Bangladesh Bureau of Statistics (BBS). 2017. Yearbook of Agricultural Statistics. Statistics and Informatics Division (SID). 28th Series. 301-302p.

[4] Srivastava, S. and Kulshreshtha, K. 2013. Nutritional Content and Significance of Tomato Powder. Annals of Arid Zone 52(2): 121-124p.

[5] Daniela, E.; Cristina M.; Casiraghi, A. R.; Rafaela, C. and Oriol M. 2013 Nutritional value of tomatoes (Solanum lycopersicum L.) grown in greenhouse by different agronomic techniques. Journal of Food Composition and Analysis. 31 (2). 245-251p.

[6] Damicone, J. P. and Brandenberger, L. 2016. Common Diseases of Tomatoes: Part I. Diseases Caused by Fungi. Oklahoma Cooperative Extension Service. EPP-7625. 1-6p.

[7] Adhikari, P.; Yeonyee, O. and Dilip, R. P. 2017. Current Status of Early Blight Resistance in Tomato: An Update. International Journal of Molecular Sciences. 1-22p.

[8] Gardener, M. B. B. and Fravel, D. R. 2002. Biological control of plant pathogens: Research, commercialization, and application in the USA. Online. Plant Health Progress doi: 10.1094/PHP-2002-0510-01-RV.

[9] Harman, G. E.; Charles, R.; Howell, A. V.; Ilan, C. and Matteo, L. 2004. Trichoderma species -opportunistic, avirulent plant symbionts. Nature Reviews Microbiology. 2: 43-56p.

[10] Blaszczyk1, L.; Siwulski2, M.; Sobieralski2, K.; Lisiecka2, J. and Jedryczka1, M. 2014. Trichoderma spp. - application and prospects for use in organic farming and industry. Journal of Plant Protection Research Vol. 54(4): 309-317p.

[11] Hermosa, R.; Viterbo, A.; Chet, I. and Monte, E. 2012. Plant-beneficial effects of Trichoderma and of its genes. 
Microbiology. 158: 17-25p.

[12] Aryal, S. 2015. Potato Dextrose Agar (PDA) - Principle, Uses, Composition, Procedure and Colony Characteristics. Online Microbiology Notes. https://microbiologyinfo.com/ potato-dextrose-agar-pda-principle-uses-composition-proc edure-and-colony-characteristics.

[13] Warcup, J.H. 1955. On the origin of colonies of fungi developing on the soil dilution plates. Transaction of the British Mycological Society. 38(3): 298-301p.

[14] Ramadas, S. 2014. https://www.researchgate.net/post/Wha t_is_the_correct_way_to_estimate_benefitcost_ratio.

[15] Shahiduzzaman. 2009. Formulation of Compost-cum-biop esticide using Municipality waste. MS thesis, Dept. of Plant Pathology.

Bangladesh

Agricultural

University,
Mymensingh. Bangladesh. 54p.

[16] Rahman, M. A.; Begum, F. M.; Alam, F. M.; Mahmud, H. and Khalequzzaman. 2010. Effect of Tricho-Compost, Compost and NPK Fertilizers on Growth, Yield and Yield Components of Chili. International Journal of Sustainable Agricultural Technology. 6(3). 64-72p.

[17] Naznin, A.; Hossain, M. M.; Ara, K. A.; Hoque, A.; Islam, M. and hasan, T. 2015. Influence of Organic Amendments and Bio-Control Agent on Yield and Quality of Tuberose. Journal of Horticulture. 2(4): 1-8p.

[18] Abd-El-Khair, H.; Khalifa, R. K. M.; Karima, H. E. and Haggag. 2010. Effect of Trichoderma species on damping off diseases incidence, some plant enzymes activity and nutritional status of bean plants. Journal of American Science. 6(9):486-497p 